\title{
LIGNOCELLULOSIC MATERIALS: A BINATIONAL PROJECT IN SINGLE CELL PROTEIN PRODUCTION
}

\section{Materiales Lignocelulósicos: Proyecto binacional en producción de aminoacidos}

\author{
Nelson Durán*, Juan $\mathbb{L}$. Reyes*, Jayme Amaya-Farfan****, \\ Elisa Esposit*, Francisco Adao*, Jaime Baeza*****, Juanita Freer*****, \\ Silvio Urizar*****, Jaime Rodríguez ${ }^{* * * *}$, Victoriano Campos***, André Ferraz ${ }^{* *}$. \\ *Instituto de Química Biological Chemistry Laboratory, \\ Universidade Estadual de Campinas, \\ C.P. 6154, Campinas, CEP 13081-970,S.P, Brazil. \\ ****Food \& Nutrition Planning, Food Engineering Faculty \\ Universidade Estadual de Campinas, Campinas,Brazil \\ ***Microbiology Laboratory, Universidad Católica de Valparaíso \\ Valparaíso, Chile \\ **Biotecnology Center, Lorena Chemical \\ Engineering Faculty, Lorena, S.P., Brazil.. \\ *****Renewable Resources Laboratory, \\ Universidad de Concepción, Concepción - Chile
}

Palabras clave: Aminoácidos, proteinas, materiales lignocelulócicos, Chrysonilia sitophila.

Key words: Amino acids, proteins, lignocellulosic materials, Chrysonilia sitophila.

\section{RESUMEN}

En este trabajo se analizan las proporciones de algunos aminoácidos de importancia nutricional en fuentes de proteinas convencionales, con las obtenidas a partir de materiales lignocelulósicos. También se comparan las reacciones de aminoácidos individuales con los aminoácidos esenciales totales $(A / E)$ y la relación entre los aminoácidos esenciales totales y los totales recuperados como nitrógeno (E/T). Estos resultados junto a los valores químicos de los aminoácidos esenciales nos permitieron comparar las cualidades de estas proteinas obtenidas de las diferentes fuentes de carbono. Este tipo de análisis permitió seleccionar las proteinas más adecuadas para una función definida, ya sea como para una ración animal o como posible alimento humano.

\section{INTRODUCTION}

Lignocellulosic materials produced in the world and their potential conversion in to special products is still an open question. For our Latinamerican countries it is even a good chance of using efficiently our natural resources, especially the forest products of low economical value which are obtained from industrial use of Pinus radiata (Chile) (e.g.

\section{SUMMARY}

Rates of some amino acids having anutritional significance in conventional protein sources together with those resulting from lignocellulosic materials are analysed here. Also a comparison of the relationship of individual amino acids to the essencial total amino acids $(A / E)$ together with the relation between the latter and the total ones recovered as nitrogen (E/T) is made. These results and chemical scores of essential amino acids allowed us to compare the qualities of these proteins obtained from the different sources of carbon. This kind of analysis made it possible to select the most suitable proteins for a particular purpose, either as animal or possible human food.

barks, tannins, phlobaphenes, carbohydrate residues from organosolv pulping, etc.), from lignocellulosic waste materials (Brazil) (rice hull, orange bagasse), and from olive milling wastewater (alpechin, Spain). Many studies in the single cell proteins (SCP) and enzyme production have been examined, but further research with new lignocellulolytic microorganisms is still necessary (Duran, 1989, 1990). The ascomycete Chrysonilia sitophila Mont von Arx (TFB- 
27441 strain) was isolated from a xilophagous insect (Campos et al. 1986; Ferraz et al. 1989). This strain, which exhibits high ligninolytic activity was efficient to degrade several organic materials (Duran et al., 1987; 1988a; 1988b; O Reilly et al., 1991; Reyes et al., 1992).

Since few lignocellulolytic microorganisms have been studied for direct SCP production from lignocellulosic materials (Tanaka et al, 1987), the $C$. sitophila (TBF-27441) as a potential microorganism for production of SCP with cellulolytic, proteolytic and ligninolytic enzymes were investigated using representative inexpensive carbon source materials from Chile, Brazil and Spain.

\section{MATERIALS AND METHODS.}

Samples: Samples of bark were taken separately from 30 years old Pinus radiata as published (Baeza et al., 1986). Phlobaphene and tannins were extracted as described previously (Baeza et al., 1985). The insoluble material after solvent extraction (bark residue) was extracted with $1 \%$ $\mathrm{NaOH}$ to remove phenolic acids. This represents the lignocellulosic residue. Samples of rice hull from Goias (Brazil) rice plantation were used. Olive milling wastewater the by product of olive oil technology was obtained from Spain (used as $10 \%$ as carbon source). Brown, pellested orange bagasse (S.P. State), milled to $1 \mathrm{~mm}$ particle size was used as the sole carbohydrate source suspended in Czapeck solution.

Sugar residues were obtained from organosolv pulping of Pinus radiata chips with formic acid and posterior lignin precipitation and exhaustive formic-water solution evaporation (Baeza et al., 1992). All the solid carbon sources were used as $1.5 \%$ concentration. The irradiation on rice hull and in olive milled wastewater were carried out with HQLOSRAM mercury vapor lamp at a flux of $68 \mathrm{~W} / \mathrm{m}^{2}$ at $300 \mathrm{~nm}$ (using glass plates as the filter) (Duran et al., 1986).

Microorganism. C. sitophila (TBF-27441 strain) was selected and cultured in a Czapek or Fries medium (Duran $e t$ al., 1988a; Ferraz et al., 1989). All the experiments were made by this method in triplicate. Amino acids from fungal mycelium were analyzed either by a Beckman Model 119 CL Amino acid Analyzer or a Aminochrom II, Labotron System. All the tables cited were averaged from duplicate hydrolysis reproductible to within $3-5 \%$.

\section{RESULTS AND DISCUSSION}

The evaluation of single cell proteins produced by $C$. sitophila with different carbon sources was perfomed.

Amino acids content of common carbon sources, as saccharose and others like wood components and ligno-cellulosic materials were determined. Most of the amino acids in all mycelial protein obtained from the substrate showed a distribution similar or higher to that of the FAO standard requirement, excepting in the methionine content using saccharose (not showed).

Methionine was deficient in rice hull, but after pre- irradiation a high content was found (10.43\%). Both sources exhibited a tyrosine and phenylalanine deficiency. A significant methionine content was observed when orange bagasse was used $(6.70 \%)$.

In Table 1 it is compared the mycelial protein, that exhibited the better qualities as compared to the FAO standard requirements, following the ratio of some essential amino acids of nutritional significance with know proteins (FAO, 1970).

Biological quality in a protein can be assessed not only by the absolute amount of each essential amino acid but also by their internal balance. Isoleucine, for example, should keep a molar ratio not lower than 1:3 (0.33) with leucine. Threonine is another essential amino acid found in short supply in vegetable proteins and encountered in high quality proteins in almost equimolar rates with serine. Table 1 shows that low quality proteins, usually of vegetable origin, are rich in arginine and histidine, in relation to lysine. These dat confirm to improvement of the internal amino acid balance throughout fermentation, with the exception of isoleucinel leucine which, nevertheless remains at acceptable values in sugar residue, rice hull and irradiated alpechin. The high lysine/arginine rate of mycelial protein when orange bagasse and alpechin/hv as inductor were used, was the result of the low level of arginine found in $C$. sitophila. Likewise, the low content of tyrosine in the fungus was responsible for the extremely low tyrosine/phenylalanine rates observed in orange bagasse, alpechin/hv and tannin cultures. Low phenylala- nine content in novel proteins would be desirable for phenylalanine intolerant individuals.

Tabla 2 shows the nutritional significant amino acid fo two known proteins as casein and egg proteins. A comparison of the rates of individual aminoacids, total essential amino acids (A/E rate) and total essential amino acid to total amino acids recovered as nitrogen ( $\mathrm{E} / \mathrm{T}$ rate), for the various substrates, is shown also in Table 2 . The E/T rates of all substrates compared rather well with those for the casein reference, while some substrate exhibited much higher values that the value of 2.02 for the $\mathrm{FAO}$ provisional reference protein (FAO-WHO, 1965). All the sustrates had A/E rates equal to or greater than those of egg protein for isoleucine,excepting by sugar residue and alpechin/hv.Leucine was equal as the standard proteins. Lysine was deficient only in bark, rice hul and tannin. In term of total aromatic compounds almost all the substrate induced a deficiency in these amino acids, except for alpechin/hv as carbon source. In general all the mycelia were sulfur compounds deficient exept for with rice hull/hv and in orange bagasse. Threonine and tryptophan were higher than the standard carbon sources. Valine was deficient in rice hull as carbon source.

Chemical scores were calculated using National Academy of Science/National Research Council Essential Amino Acids Scoring Pattern (NAS, 1980) (Table 3). The total sulphur-containing amino acids were the most limiting amino acid in the proteins obtained when saccharose, rice hull, alpechin/hv, tannin and phlobaphene were used as substrates. Higher values than those of the standard proteins in the case of sugar residue and rice hull/hv were obtained. Histidine the 
Table 1. Rates of some aminoacids of nutritional significance in conventional and non-conventional protein sources (FAO. 1970).

\begin{tabular}{|c|c|c|c|c|c|}
\hline Source & ILE/LEU & TYR/PHE & LYS/HIS & LYS/ARG & THR/SER \\
\hline Milk & 0.65 & 1.05 & 2.95 & 2.12 & 0.78 \\
\hline Egg(Whole) & 0.75 & 0.74 & 2.66 & 2.66 & 0.59 \\
\hline Meat (bovine) & 0.64 & 0.82 & 2.51 & 1.35 & 1.05 \\
\hline Rice & 0.54 & 0.91 & 2.34 & 0.68 & 0.77 \\
\hline Maize & 0.35 & 1.34 & 1.39 & 0.82 & 0.70 \\
\hline Sorghum & 0.34 & 0.55 & 1.41 & 0.72 & 0.71 \\
\hline Wheat Flour & 0.67 & 0.46 & 1.69 & 0.76 & \\
\hline Peanuts & 0.67 & 0.71 & 1.45 & 0.33 & 0.40 \\
\hline Yeast & 0.57 & 0.95 & 2.58 & 1.70 & 1.04 \\
\hline Orange Waste & 0.83 & 0.49 & 1.15 & 0.60 & 0.94 (a) \\
\hline FAO & 0.88 & 1.00 & & & \\
\hline Soybean & 0.75 & 0.75 & 2.34 & 0.93 & 0.93 \\
\hline Casein & 0.54 & 1.10 & 3.95 & $2-03$ & 0.73 \\
\hline \multicolumn{6}{|l|}{ SCP } \\
\hline \multicolumn{6}{|l|}{ Induced By: } \\
\hline Orange Waste & 0.68 & 0.02 & 2.69 & 4.31 & 1.08 \\
\hline Saccharose & 0.76 & 0.95 & 2.59 & 1.42 & 1.12 \\
\hline Sugar Residue & 0.30 & 0.82 & 2.33 & 0.88 & 0.85 \\
\hline Bark & 1.47 & 1.02 & 3.78 & 1.78 & 0.75 \\
\hline Rice Hull & 0.37 & 1.00 & -- & 1.86 & 2.90 \\
\hline Rice Hull/hv & - & 1.00 & -- & -- & 0.84 \\
\hline Alpechin & 0.58 & 0.64 & 3.30 & 1.49 & 1.25 \\
\hline Alpechin/hv & 0.35 & 0.29 & 4.75 & 4.00 & 1.12 \\
\hline Lignocel.Res & 0.73 & 0.87 & 2.45 & 1.10 & 1.08 \\
\hline Tannin & 0.81 & 0.14 & 0.56 & 0.27 & 1.12 \\
\hline Phlobaphene & 1.18 & 0.87 & 2.68 & 0.60 & 0.78 \\
\hline
\end{tabular}

a) Reyes et al 1992 .

Table 2. Nutritional Significant Amino Acids (a,b).

\begin{tabular}{|lrrrrrrrrrrrrr|}
\hline A/rate (c) & S. & B. & SR. & R. & Rhv & AL. & ALhv & L. & O. & T. PHL & C. & E \\
& & & & & & & & & & & & & \\
Isoleucine & 126 & 263 & 78 & 102 & 0.3 & 109 & 90 & 141 & 103 & 180 & 220 & 106 & 129 \\
Leucine & 167 & 186 & 261 & 273 & 304 & 187 & 254 & 189 & 150 & 223 & 187 & 194 & 172 \\
Lysine & 144 & 96 & 136 & 95 & 158 & 147 & 158 & 152 & 159 & 30 & 122 & 169 & 125 \\
Total arom. & 176 & 128 & 194 & 0.6 & 0.6 & 155 & 211 & 165 & 85 & 115 & 149 & 226 & 194 \\
Phenylalani & 90 & 63 & 107 & 0.3 & 0.3 & 94 & 163 & 88 & 83 & 101 & 80 & 108 & 114 \\
Tyrosine & 86 & 66 & 97 & 0.3 & 0.3 & 61 & 48 & 77 & 2 & 14 & 69 & 118 & 81 \\
Total Sulfur conta- & & & & & & & & & & & & & \\
ining Amino acids & 36 & 53 & 78 & 0.6 & 301 & 38 & 17 & 19 & 148 & 53 & 25 & 52 & 107 \\
Cysteine & 2 & 0.2 & 39 & 0.3 & 0 & 19 & 0.2 & 2 & 0.2 & 2 & 11 & 6 & 46 \\
Methionine & 34 & 53 & 39 & 0.3 & 301 & 19 & 17 & 17 & 148 & 15 & 51 & 51 & 61 \\
Threonine & 148 & 103 & 107 & 495 & 197 & 105 & 115 & 128 & 140 & 152 & 111 & 88 & 99 \\
Trytophan & 37 & 27 & 30 & 33 & 38 & 27 & 27 & 35 & 29 & 35 & 32 & 24 & 31 \\
Valine & 167 & 135 & 116 & 0.3 & 0.3 & 260 & 128 & .151 & 186 & 214 & 155 & 137 & 141 \\
& & & & & & & & & & & & \\
E/Rate (d) & 2.4 & 3.2 & 2.7 & 2.4 & 2.2 & 3.1 & 3.0 & 2.5 & 2.8 & 2.36 & 2.6 & 2.9 & 3.2 \\
& & & & & & & & & & & & (e) & (f) \\
\hline
\end{tabular}

a) S=Saccharose; B: Bark; SR: Sugar residue; R: Rice hull; Rhv: Rice hull irradiated; AL: Alpechin;Alhv: Alpechin irradiated; L:Lignocellulosic residue; C: Casein; E: Eggs; O: Orange residue; T:Tannin;PHL:Phobaphene. (b) Trytophan taken as minimum of $1.3 \mathrm{~g}$ per $16 \mathrm{~g} \mathrm{~N}$; (c) Individual amino acid (mg) per $\mathrm{g}$ of total essential amino acids; (d) Total essential amino acids ( $\mathrm{g}$ of amino acid) per g of total recovered nitrogen; (e) Calculated form data Ref.(Dong et al., 1987); (f) Ref. (Houston et al.,1969). 


\begin{tabular}{|c|c|c|c|c|c|c|c|c|c|c|c|c|}
\hline \multirow{2}{*}{$\begin{array}{l}\text { Amino } \\
\text { Acid }\end{array}$} & \multicolumn{12}{|c|}{ Table 3. Chemical scores calculated limiting Amino Acids (a,b). } \\
\hline & $\mathbf{C}$ & S. & B. & SR. & $\mathbf{R}$ & Rhv & AL. & Alhv & $\mathbf{L}$. & o. & T. & PHL \\
\hline H. & 118 & 127 & 77 & 140 & 0.6 & 0.6 & 123 & 94 & 150 & 155 & 120 & 115 \\
\hline I & 116 & 117 & 333 & 80 & 95 & 0.2 & 124 & 102 & 128 & 109 & 164 & 222 \\
\hline $\mathbb{L}$ & 129 & 93 & 136 & 162 & 152 & 150 & 128 & 174 & 113 & 96 & 123 & 144 \\
\hline Ly & 154 & 109 & 98 & 115 & 73 & 107 & 137 & 149 & 123 & 139 & 22 & 102 \\
\hline Th & 117 & 163 & 150 & 132 & 555 & 195 & 143 & 157 & 151 & 179 & 166 & 135 \\
\hline Try & 100 & 118 & 118 & 118 & 118 & 118 & 118 & 118 & 118 & 118 & 118 & 118 \\
\hline $\mathbf{V a}$ & 133 & 134 & 145 & 105 & 0.2 & 0.2 & 258 & 128 & 131 & 172 & 170 & 137 \\
\hline TSC & 102 & 54 & 105 & 129 & 0.8 & 401 & 69 & 31 & 29 & 252 & 77 & 42 \\
\hline TAA & 144 & 93 & 90 & 115 & 0.3 & 0.3 & 101 & 138 & 95 & 51 & 60 & 86 \\
\hline
\end{tabular}

a) Abbreviation as Table 2; b) calculated using the scoring in NAS (1980) calculations based on total amino acids recovery. Chemical score ( $\mathrm{g}$ aminoacid/16 $\mathrm{g}$ of test protein)(g amino acid/16 $\mathrm{g}$ of reference pattern) $\mathrm{x} 100$.

second limiting factor with all the substrates.

Although chemical scores have inherent limitations and therefore are only an approximation of the nutritional quality (Dong et al., 1987), these values are complements of those obtained with the other methods.

In summary, considering the casein as pattern, the rate of important amino acids of significant nutritional values, $\mathrm{E} / \mathrm{T}$ and $\mathrm{A} / \mathrm{E}$ rates together with chemical scores indicated in our case that bark, orange bagasse and alpechin are the best carbon source for good quality single cell protein from C. sitophila.

\section{Acknowledgement}

Support from FASESP, FINEP and CNPq (Brazil) and FONDEF and FONDECYT (Chile) is acknowledged.

\section{REFERENCES}

Food Policy and Food Science Service, Nutrition Div.FAO.(1970). Amino Acid content of foods and biological data on proteins. FAO nutritional studies. Publication N 24, Rome, Italy.

Baeza,J.;Freer,J.; Rojas,N.; Palma,G.; Duran,N.(1986). Characte-rization of polyphenols extracted from wood. Bol. Soc. Chil. Quim 31:115-121

Baeza, J.;Freer,J.; Rojas, N.; Duran,N. (1985). A conductometric method for determination of phenolic groups in phobaphene and tannins from wood. Analyst. 110:1407-1409

Baeza, J.; Urizar,S.;Erismann, N de M.;Freer,J.; Schmidt,E.; Duran,N. (1992). Organosolv pulping V: Formic acid delignification of Eucalyptus grandis and Eucalyptus globulus. Bioresource Technol. 37:1-6

Campos, V.;Salas, E.;Duran, N.; Rodríguez, J.; Baeza,J. (1986). Isolation of cellulolytic Chrysonilia sitophila from Tribolium ferrugineus. Bol. Micol. 2:161-165

Dong, F.M.; Rasco,B.A.; Gazzaz, S.S. (1987). A protein quality assessment of wheat and corn distillers'dried grains with soluble. Cereal Chem. 64:327332

Duran, N. (1989). Bioconversion to single cell protein: Recovery of lignocellulosic materials to produce human food as an integrated process. Part 1. Alimentos (Chile) 14: 39-50
Duran, N. (1990). Bioconversion to single cell protein: Recovery of lignocellulosic materials to produce human food as an integrated process. Part 2. Alimentos (Chile). 15: 51-61

Duran, N. \&. Gomez,E. (1986). Biomass Photochemistry-IX:Photochemical pretreatment of cellulose and its effect on cellulase effciency.J. Photochem. 35:109. 115.

Duran, N.;Reyes,J.L.;Baeza,J.; Campos,V. (1988a). Biomass photochemistry XII: Chemical and photochemical pre-treatment of rice hull and its fungal degradation. Biotechnol. Bioeng.32: 564-568

Duran, N.;Rodríguez, J.;Gomes, E.;Campos,V.;Baeza,J. (1988b). Biomass photochemistry: XI Photochemical pre-treatment of cellulose and its fungal degradation. Biotechnol. Bioeng. 31:215-219

Duran, N.;Rodriguez, J.;Ferraz,A.;Campos,V.(1987). Chrysonilia sitophila (TFB-27441): A hyperlignilolytic strain. Biotechnol. Lett. 9:357-360

FAO-WHO, Protein requiriments report by a joint FAO-WHO expert group.(1965). World Health Org. Tech. Rep. Ser. N301.

Ferraz, A. \& Duran, N.(1989). Effect of various conditions of the Chrysonilia sitophila (TBF-27441) growth. Rev. Microbiol.20:240-245

Houston, D,F.; Allis, M.E.; Kohler, G.O. (1969). Aminoacid composition of rice and rice by-products. Cereal Chem. 46:527-537

National Academy of Science (NAS).(1980). Recommended dietary alowance, NAS, Washington, DC,pp. 39-54.

O' Reilly, S.; Erazo, S.; Campos,V.; Salas,E.; Baeza,J.; Ferraz,A.; Rodríguez,J. Duran,N. (1991). The effect of carbon sources on the single cell proteins and extracellular enzymes production by Chrysonilia sitophila (TBF-27441). Appl. Biochem. Biotechnol. 27:267-276

Reyes, J.L.; Amaya-Farfan, J.;Duran,N. (1992). Utilization of lignocellulosic materials: Orange waste as carbon source for single cell protein. Proc. Second Braz. Symp. on Chem. of Lignin and other Wood Components (N. Duran and E. Esposito,Eds.) FASESP Publ. (Campinas, S. P. Brazil)pp.410-415

Tanaka, M.\& Matsuno,R. (1987). Conversion of lignocellulosic materials to single cell proteins (SCP): Recent development and problems. Enzyme Microbiol. Technol. 7: 197-206. 